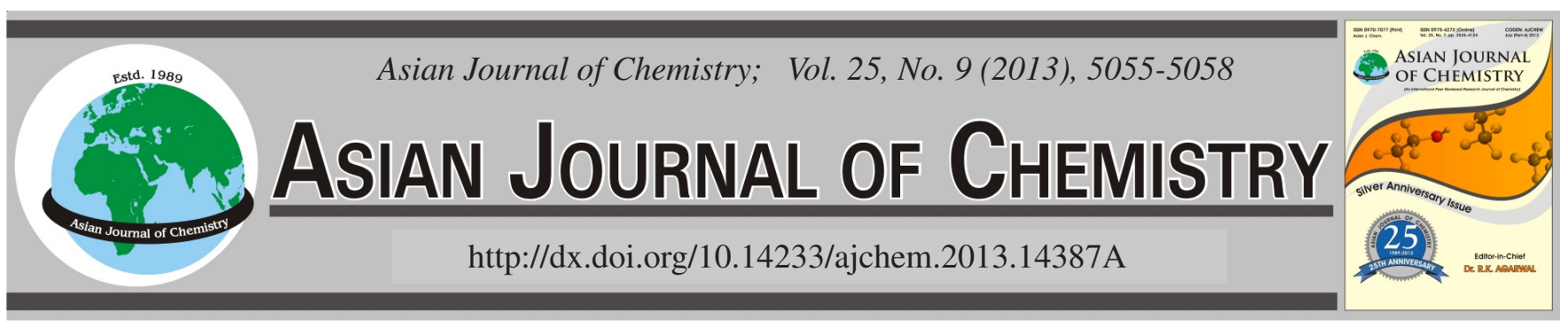

\title{
Composition, Antimicrobial and Antioxidant Activities of the Essential Oil of Murraya exotica from Hainan of China
}

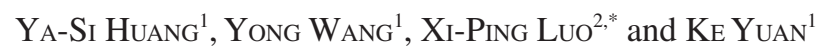

${ }^{1}$ The Nurturing Station for the State Key Laboratory of Subtropical Silviculture, Zhejiang Agriculture and Forestry University, Lin'an, 311300 , P.R. China

${ }^{2}$ School of Environmental \& Resource Sciences, Zhejiang Agriculture and Forestry University, Lin'an, 311300, P.R. China

*Corresponding author: Tel: +86 57163732747; E-mail: luoxiping0571@163.com

(Received: 2 August 2012;

Accepted: 20 March 2013)

AJC-13136

\begin{abstract}
The objective of the works reported here was to make a thorough inquiry of composition, antimicrobial and antioxidant activities of the essential oil of Murraya exotica from Hainan Province, China. The essential oil of Murraya exotica were extracted by hydrodistillation and analyzed by GC and GC/MS. The relative content of each peak were detected by the normalization method of peak area. Thrity four components of Murraya exotica essential oil were identified which accounted for $97.76 \%$ of total essential oil and the content of caryophyllene was up to $45.51 \%$, particularly. The results of the antioxidant activity test showed that the volatile oil had significant free radical scavenging capacity $\left(\mathrm{IC}_{50}=0.1511\right.$ ). The antibacterial test results showed that the volatile oil of Murraya exotica had broadspectrum antimicrobial activity on all bacteria other than Pseudomonas aeruginosa. Of which, the inhibition to Bacillus subtilis was about four times of the positive control and had a certain antifungal capabilities. Volatile oil of Murraya exotica had a certain antioxidant and antibacterial activity. The results can provide reference for further research on the chemical components of Murraya exotica volatile oil as well as for the exploration and utilization of it.
\end{abstract}

Key Words: Murraya exotica, GC-GC/MS, Antioxidant, Antimicrobial.

\section{INTRODUCTION}

The genus of Murraya L. belonging to the family Rutaceae of the Rutales is a kind of ornamental bush or small macrophanerophytes which contains 12 species and is widely distributed in southern Asia and northeastern Australia ${ }^{1}$. Murraya exotica (M. exotica) is the model of the family and the leaves of this plant called curry leaf are known as a kind of condiment which has been used popularly in Indian cooking ${ }^{2}$. It is reported that $M$. exotica has also played an important role in folk medicine in eastern Asia and Australia, where it is used to cure indigestion, vomit and relieve nausea ${ }^{3}$. According to Li et al. ${ }^{4}$, essential oil of $M$. exotica show definite toxicity against $S$. zeamais, T. castaneum adults and Calletotrichum musae. However, the study on its anti-pathogenic bacteria was absolute a gap. For this reason, this work reported here was urgently needed for searching natural germifuga and antioxidant.

\section{EXPERIMENTAL}

The fresh leaves of M. exotica were collected from Hainan province, China. The leaves were washed gently and dried in the sky. The dried samples were powdered with a blender and passed through an 80-mesh sieve and placed in bags and immediately stored in a desicator. Standard solution of the $n$-alkanes $\mathrm{C}_{8}-\mathrm{C}_{20}$ and $\mathrm{C}_{21}-\mathrm{C}_{40}$ mixture, DPPH and Trolox were all purchased from the Sigma Chemical Co, USA. The test bacterial strain used in this study were Staphylococcus aureus, Bacillus subtilis, Pseudomonas aeruginosa and Escherichia coli (freeze-dried powder) obtained from the Beijing Lianchuang Biotechnologies Institute. Fusarium graminearum, Botrytis cinerea, Exerohilum turcicum and Lecannosticta acicola were provided by the microbiology laboratory in Zhejiang Agriculture and Forestry University. The purity of the standards were all above $99.5 \%$. The main instruments used in this work were volatile oil extraction device and GC-MS analysis of the oils were carried out on a Trace 2000 instrument (Finnigan MS Co., USA), equipped with FID and DB-WAX elastic quartz capillary-tube chromatographic column $(30 \mathrm{~m} \times 0.25 \mathrm{~mm}, 0.25 \mathrm{~mm})$. Infinite M 200 Enzyme Microplate Reader (Switzerland Tecan) was used in determination of antioxidation activity.

Extraction of essential oil: Dried leaves powder ( $c a$. $50 \mathrm{~g}$ ) were swollen with $500 \mathrm{~mL}$ distilled water in a standard extractor for $12 \mathrm{~h}$, then were extracted by hydrodistillation in a Clevenger-type apparatus for $4 \mathrm{~h}$ procedure described in the 
Chinese Pharmacopoeia $(2005)^{5}$. Collect the steam liquid and extract it with ether, then recycle the ether and the oil was obtained after dehydration with anhydrous sodium sulfate. The essential oil samples were stored at $4{ }^{\circ} \mathrm{C}$ in dark before analysis. The yield of the essential oil was $1.32 \%(\mathrm{v} / \mathrm{w}$ of dried sample).

GC-MS analysis: A FID and DB-WAX elastic quartz capillary-tube chromatographic column $(30 \mathrm{~m} \times 0.25 \mathrm{~mm}$ i.d., $0.25 \mu \mathrm{m})$ : Agilent J \& W scientific, Folsom, CA, USA) was used to separate the essential oil components. The initial temperature of the oven was held at $45^{\circ} \mathrm{C}$ for $3 \mathrm{~min}$, increased to $100^{\circ} \mathrm{C}$ with the rate of $10^{\circ} \mathrm{C} \mathrm{min}^{-1}$, then increased to $170{ }^{\circ} \mathrm{C}$ at $4{ }^{\circ} \mathrm{C} \mathrm{min}^{-1}$, of which the final temperature was increased to $240{ }^{\circ} \mathrm{C}$ at the rate of $10{ }^{\circ} \mathrm{C} \mathrm{min}^{-1}$ and held for $7 \mathrm{~min}$. The ion source and injector temperatures were 200 and $250{ }^{\circ} \mathrm{C}$, respectively. The spectrometers were operated in electronimpact (EI) mode; the ionization energy was $70 \mathrm{eV}$ with a mass range of $40-300 \mathrm{~m} \mathrm{z}^{-1}$ and a scan interval of $0.5 \mathrm{~s}$. The detector potential was $350 \mathrm{~V}$ and the solvent delay time was 3 min. Helium was used as carrier gas at a constant flow rate of $0.8 \mathrm{~mL} \mathrm{~min}^{-1}$ flow-rate.

Calculation of retention indices: This quasi-linear equation proposed by Van den Dool and $\mathrm{Kratz}^{6}$ was used to calculate retention indices in this work:

$$
\mathrm{IT}=100 \times \mathrm{n}+100 \times \frac{(\mathrm{tx}-\mathrm{tn})}{(\mathrm{tn}+1-\mathrm{tn})}
$$

where IT is the temperature-programmed retention index of the interesting compound and $\mathrm{tn}, \mathrm{tn}+1$ and $\mathrm{tx}$ are the retention times of the two standard $n$-alkanes containing $n$ and $n+1$ carbons and the compound of interest, respectively.

Determination of antioxidation activity: The free radical scavenging activity of essential oils were determined based on their ability to react with the DPPH (2,2'-diphenyl-1picrylhydrazyl) free radical with micro-plate quantification method $^{7} .14 .00 \mathrm{mg}$ of Trolox was dissolved in ethanol and diluted to $50 \mathrm{~mL}$, then diluted to $0.056,0.112,0.168,0.196$, $0.224,0.224$ and $0.280 \mathrm{mg} \mathrm{mL}^{-1}$, respectively. Essential oil samples were dissolved to $0.01,0.02,0.04,0.06,0.08$ and $0.10 \mathrm{mg} \mathrm{mL}^{-1}$ by ethanol. $15.56 \mathrm{mg}$ DPPH was dissolved in ethanol and diluted to $50 \mathrm{~mL}\left(0.3112 \mathrm{mg} \mathrm{mL}^{-1}\right) .100 \mu \mathrm{L}$ essential oil samples of all the concentrations in which 200 $\mu \mathrm{L}$ DPPH were added to micro-plate incubated at $25^{\circ} \mathrm{C}$ for $0.5 \mathrm{~h}$, then the ultraviolet absorption (As) was determined at $517 \mathrm{~nm}$. The antioxidant activity (\%) of radical-scavengers was calculated as followed:

$$
\text { Scavenging }(\%)=\frac{1-\left(\mathrm{A}_{\mathrm{s}}-\mathrm{A}_{\mathrm{r}}\right)}{\mathrm{A}_{0}} \times 100 \%
$$

where $A_{s}$ is the absorbance of $50 \mu \mathrm{L}$ sample mixed with 200 $\mu \mathrm{L}$ DPPH solution, while $\mathrm{A}_{\mathrm{r}}$ is the absorbance of blank sample without DPPH and $A_{0}$ is the absorbance of $50 \mu \mathrm{L}$ absolute ethyl alcohol mixed with $200 \mu \mathrm{L}$ DPPH solution, parallel tests were carried out 3 times in every experiments at $517 \mathrm{~nm}$ and $\mathrm{IC}_{50}$ values were reported as mean value of triplicates.

Determination of antimicrobial activity: By oxford cup method $^{8}$, inhibition zone were used to estimate the antibacterial ability of the essential oil ${ }^{8}$. $50 \mu \mathrm{L}$ of essential oil was dissolved diethyl ether and diluted to $2 \mathrm{~mL}$. Four species of fungi were spread on the potato culture medium and four species of bacteria $\left(10^{7}-10^{8} \mathrm{cfu} \mathrm{L^{-1 } )}\right.$ were spread on the agar culture medium. Then the oxford cup was put on the middle of the plates which contained $200 \mu \mathrm{L}$ oil samples $\left(10 \mu \mathrm{L} \mathrm{mL}^{-1}\right)$ as well as positive and negative controls. After the plates were incubated at $37^{\circ} \mathrm{C}$ for $24 \mathrm{~h}$, the Inhibition zone was observed. The positive controls used gentamicin $\left(80 \mathrm{U} \mathrm{mL}^{-1}\right)$ and the negative controls used diethyl ether for each strain assay and the diameters of the inhibition zones were measured in $\mathrm{mm}$. All the assays were performed in triplicate.

\section{RESULTS AND DISCUSSION}

GC-MS Analysis: GC-MS total ion current chromatogram of the essential oil from the Murraya exotica is given in Fig. 1. The relative content of each peak was detected by the normalization method of peak area. By searching in NIST2008 standard mass spectrometry library and calculating with the normalization method of peak area, 34 compounds were identified (Table-1).

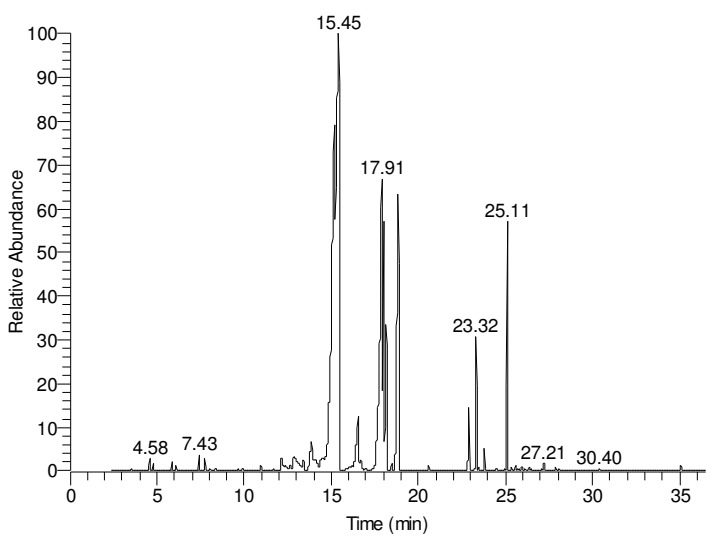

Fig. 1. GC-MS total ion current chromatogram of the essential oil from the Murraya exotica

As listed in Table-1, 48 peaks are separated in the essential oil of M. exotica, of which 34 compounds are identified and most of that belonged to sesquiterpenoids, such as carypohyllene, cedrene $(15.12 \%)$ and 1-(1,5-dimethyl-4-hexenyl)-4-methylbenzene $(11.12 \%)$ and the relative content of carypohyllene was up to $45.51 \%$.

Antioxidant activity analysis: DPPH method was used to determine the free radical scavenging capacity of volatile oil from $M$. exotica. Trolox in different concentrations were determined and the results were calculated by regression analysis. According to the regression equation, $\mathrm{IC}_{50}$ were obtained and listed in Table-2.

Table-2 shows that there is favourable linear relationship between the free radical scavenging capacity of essential oil and its concentration and its $\mathrm{IC}_{50}(0.1511)$ is less then Trolox (0.1879).

Antibacterial activity analysis: Oxford cup method was used to analyze the antibacterial activity of the essential oil of M. exotica with gentamycin as positive control and ether as negative control. According to the inhibition zone, the antibacterial abilities were evaluated and the results could be seen in Table-3. 


\begin{tabular}{|c|c|c|c|c|c|}
\hline \multicolumn{6}{|c|}{$\begin{array}{c}\text { TABLE-1 } \\
\text { CHEMICAL COMPOSITION OF VOLATILE OIL IN THE Murraya exotica }\end{array}$} \\
\hline No. & Name of components & $\mathrm{RT}(\min )$ & m.f. & RI & Relative concent (\%) \\
\hline 1 & 1R- $\alpha$-Pinene & 4.58 & $\mathrm{C}_{10} \mathrm{H}_{16}$ & 1018 & 0.29 \\
\hline 2 & R(-)3,7-Dimethyl-1,6-octadiene & 4.80 & $\mathrm{C}_{10} \mathrm{H}_{18}$ & 1031 & 0.10 \\
\hline 3 & Eucalyptol & 7.75 & $\mathrm{C}_{10} \mathrm{H}_{18} \mathrm{O}$ & 1201 & 0.17 \\
\hline 4 & D-Limonene & 7.43 & $\mathrm{C}_{10} \mathrm{H}_{16}$ & 1222 & 0.23 \\
\hline 5 & Benzaldehyde & 13.40 & $\mathrm{C}_{7} \mathrm{H}_{6} \mathrm{O}$ & 1338 & 0.19 \\
\hline 6 & $\alpha$-Cubebene & 12.14 & $\mathrm{C}_{15} \mathrm{H}_{24}$ & 1454 & 0.43 \\
\hline 7 & Copaene & 12.30 & $\mathrm{C}_{15} \mathrm{H}_{24}$ & 1462 & 0.22 \\
\hline 8 & Nonanal & 10.97 & $\mathrm{C}_{15} \mathrm{H}_{24}$ & 1475 & 0.08 \\
\hline 9 & $\beta$-Elemene & 12.65 & $\mathrm{C}_{15} \mathrm{H}_{24}$ & 1479 & 0.08 \\
\hline 10 & $\begin{array}{l}\text { Octahydro-7-methyl-3-methylene-4-(1-methylethyl)- } 1 \mathrm{H} \text {-cyclopenta[1,3] } \\
\text { cyclopropa[1,2]benzene }\end{array}$ & 13.79 & $\mathrm{C}_{15} \mathrm{H}_{24}$ & 1535 & 2.01 \\
\hline 11 & 2,6-Dimethyl-6-(4-methyl-3-pentenyl)-bicyclo[3.1.1]hept-2-ene & 14.41 & $\mathrm{C}_{15} \mathrm{H}_{24}$ & 1566 & 0.61 \\
\hline 12 & Caryophyllene & 15.20 & $\mathrm{C}_{15} \mathrm{H}_{24}$ & 1604 & 45.51 \\
\hline 13 & $\begin{array}{l}\text { (1S-Endo)-2-methyl-3-methylene-2-(4-methyl-3-pentenyl)-bicyclo[2.2.1] } \\
\text { heptane }\end{array}$ & 15.96 & $\mathrm{C}_{15} \mathrm{H}_{24}$ & 1642 & 0.07 \\
\hline 14 & (E)-7,11-Dimethyl-3-methylene-1,6,10-Dodecatriene & 16.46 & $\mathrm{C}_{15} \mathrm{H}_{24}$ & 1667 & 0.82 \\
\hline 15 & (Z)- 7,11-Dimethyl-3-methylene-1,6,10-Dodecatriene & 16.55 & $\mathrm{C}_{15} \mathrm{H}_{24}$ & 1671 & 1.71 \\
\hline 16 & $\alpha$-Caryophyllene & 16.70 & $\mathrm{C}_{15} \mathrm{H}_{24}$ & 1678 & 0.33 \\
\hline 17 & Cedrene & 17.91 & $\mathrm{C}_{15} \mathrm{H}_{24}$ & 1738 & 15.12 \\
\hline 18 & $\begin{array}{l}2,4 \alpha, 5,6,7,8,9,9 \mathrm{a}-\text { octahydro-3,5,5-trimethyl-9-methylene- } 1 \mathrm{H} \text {-benzocyclo- } \\
\text { heptene }\end{array}$ & 18.01 & $\mathrm{C}_{15} \mathrm{H}_{24}$ & 1743 & 5.35 \\
\hline 19 & $\begin{array}{l}\text { 1-Ethenyl-1-methyl-2-(1-methylethenyl)-4-(1-methylethylidene)- } \\
\text { cyclohexane }\end{array}$ & 18.15 & $\mathrm{C}_{15} \mathrm{H}_{24}$ & 1750 & 4.19 \\
\hline 20 & $\begin{array}{l}\text { 3,3,6,6,9,9-Hexamethyl-Z,Z,E-(1-methylethylidene)-cyclohexanetetracyclo } \\
{[6.1 .0 .0(2,4) .0(5,7)] \text { nonane }}\end{array}$ & 18.51 & $\mathrm{C}_{15} \mathrm{H}_{24}$ & 1767 & 0.23 \\
\hline 21 & 1-(1,5-Dimethyl-4-hexenyl)-4-methyl-benzene & 18.83 & $\mathrm{C}_{15} \mathrm{H}_{22}$ & 1783 & 11.12 \\
\hline 22 & (Z)- 5-(1-Propenyl)-1,3-benzodioxole & 20.58 & $\mathrm{C}_{10} \mathrm{H}_{10} \mathrm{O}_{2}$ & 1943 & 0.10 \\
\hline 23 & Caryophyllene oxide & 22.91 & $\mathrm{C}_{15} \mathrm{H}_{24} \mathrm{O}$ & 1984 & 1.31 \\
\hline 24 & Z- $\alpha$-Trans-bergamotol & 23.41 & $\mathrm{C}_{15} \mathrm{H}_{24} \mathrm{O}$ & 2009 & 0.09 \\
\hline 25 & 3,7,11-Trimethyl-1,6,10-dodecatrien-3-ol & 23.79 & $\mathrm{C}_{15} \mathrm{H}_{26} \mathrm{O}$ & 2028 & 0.31 \\
\hline 26 & (E,E)-12-Methyl-1,5,9,11-tridecatetraene & 23.86 & $\mathrm{C}_{14} \mathrm{H}_{22}$ & 2056 & 0.05 \\
\hline 27 & (-)-Spathulenol & 25.11 & $\mathrm{C}_{15} \mathrm{H}_{24} \mathrm{O}$ & 2093 & 4.44 \\
\hline 28 & Trans-Z- $\alpha$-bisabolene epoxide & 25.34 & $\mathrm{C}_{15} \mathrm{H}_{24} \mathrm{O}$ & 2104 & 0.05 \\
\hline 29 & 1,2-Dimethoxy-4-(2-propenyl)-benzene & 23.32 & $\mathrm{C}_{11} \mathrm{H}_{14}$ & 2113 & 2.05 \\
\hline 30 & cis-Lanceol & 25.79 & $\mathrm{C}_{15} \mathrm{H}_{24} \mathrm{O}$ & 2126 & 0.05 \\
\hline 31 & Z- $\alpha$-Trans-bergamotol & 25.95 & $\mathrm{C}_{15} \mathrm{H}_{24} \mathrm{O}$ & 2134 & 0.06 \\
\hline 32 & Decahydro-1,1,7-trimethyl-4-methylene- $1 H$-cycloprop[e]azulen-7-ol & 26.37 & $\mathrm{C}_{15} \mathrm{H}_{24} \mathrm{O}$ & 2155 & 0.05 \\
\hline 33 & Octahydro-1,4,9,9-tetramethyl-1H-3 $\alpha, 7$-Methanoazulene & 27.21 & $\mathrm{C}_{15} \mathrm{H}_{26}$ & 2196 & 0.10 \\
\hline 34 & $n$-Hexadecanoic acid & 35.07 & $\mathrm{C}_{16} \mathrm{H}_{32} \mathrm{O}_{2}$ & 2555 & 0.15 \\
\hline Total & & & & & 97.67 \\
\hline
\end{tabular}

\begin{tabular}{lccc}
\hline \multicolumn{5}{c}{ TABLE-2 } \\
ANTIOXIDANT ACTIVITY OF THE ESSENTIAL \\
OIL FROM THE MURRAYA EXOTICA GIVEN \\
AS IC S0 $_{50}$ AND REGRESSION EQUATIONS \\
\hline \multicolumn{1}{c}{ Samples } & Regression equation & $\mathrm{R}^{2}$ & $\mathrm{IC}_{50}$ \\
\hline M. exotica & $\mathrm{y}=0.1309 \mathrm{x}+0.0093$ & 0.9919 & 0.1511 \\
Trolox & $\mathrm{y}=1.844 \mathrm{x}+0.1535$ & 0.9901 & 0.1879 \\
\hline
\end{tabular}

As listed in Table-3, the essential oil of $M$. exotica displayed abroad spectrum antibacterial activity to the bacteria apart from Pseudomonas aeruginosa. Particularly, Bacillus subtilis was highly controlled, as it was almost 4 times of the antibacterial activity of positive control, which corresponded to Escherichia coli and Staphylococcus aureus, respectively. Oppositely, the fungus were not inhibited greatly by the essential oil, as the antibacterial activity of Lecannosticta acicola was nearly equivalent to the positive control and the antibacterial activity of Botrytis cinerea was obviously less than the positive control.

\begin{tabular}{|c|c|c|c|}
\hline \multicolumn{4}{|c|}{$\begin{array}{l}\text { TABLE-3 } \\
\text { INHIBITION ZONE OF ESSENTIAL OIL IN } M \text {. exotica In } \\
\text { MICROBIOLOGICAL ASSAYS BY CUP OXFORD METHOD }\end{array}$} \\
\hline \multirow[b]{2}{*}{ Microorganism } & \multicolumn{3}{|c|}{ Inhibition zone (mm) } \\
\hline & $\begin{array}{c}M . \\
\text { exotica }\end{array}$ & $\begin{array}{c}\text { Positive } \\
\text { control }\end{array}$ & $\begin{array}{c}\text { Negative } \\
\text { control }\end{array}$ \\
\hline Escherichia coli & 39.60 & 29.73 & + \\
\hline Staphylococcus aureus & 12.07 & 14.51 & + \\
\hline Bacillus subtilis & 43.13 & 12.73 & + \\
\hline Pseudomonas aeruginosa & - & 13.65 & + \\
\hline Botrytis cinerea & 12.00 & 13.03 & + \\
\hline Fusarium graminearum & - & 15.80 & + \\
\hline Exerohilum turcicum & - & 14.60 & + \\
\hline Lecannosticta acicola & 11.86 & 13.36 & + \\
\hline
\end{tabular}

\section{Conclusion}

Here, we had identified 34 essential chemical compounds in M. exotica, of which caryophyllene was the highest content 
and accounted for almost half of the essential oil. One of the most common content of plant essential oil is caryophyllene, a kind of bicyclic sesquiterpenes and had always been used as spice, however, its antioxidant activity had not been comprehensively illustrated yet. Donatelli and Buffon ${ }^{9}$ had demonstrated that $\beta$-caryophyllene had anaesthetic effects using procaine as control. But further researches aiming at its antimicrobial had never been performed. Moreover, in the current studies, we hadn't found such a high content of caryophyllene in other aromatic plants as that in $M$. exotica. Hence, we proposed that caryophyllene should play a key role in the antioxidant activity and antimicrobial effect of $M$. exotica.

In this study, we showed that $M$. exotica greatly inhibited Bacillus subtilis and its inhibitory capability was about 4 times higher than the positive control. Until now, natural antibacillus subtilis chemical medicine hasn't been found while those harmful traditional pesticide residues, such as bordeaux mixture and carbendazim require continuous use, which might cause serious pesticide residue in woods and soil and result in the drug resistance of germs. Therefore, the anitfungal activity of M. exotica volatile oil has wide application value.

M. exotica is one of the most common shrubs in Hainan Province with abundant resource, has not been efficiently utilized yet. Researches on the antioxidant activity of volatile oil in Indian $M$. exotica, which is much more worthy than being exploited, have already drawn certain attentions. The results of this study have provided basis for further usage of Hainan M. exotica resources.

\section{ACKNOWLEDGEMENTS}

The authors are grateful to the Center of Analysis and Testing, Jiangnan University, for performing GC-MS and also to the Zhejiang Agriculture and Forestry University, for performing Universal Microplate Spectrophotometer.

\section{REFERENCES}

1. Flora Reipublicae Popularis Sinicae, Beijing:Science Press, 43, 143 (1990).

2. J.S. Pruthi, Spices and Condiments, New Delhi, National Book Trust, p. 108 (1976).

3. P. Gupta, A. Nahata and V. K. Dixit, J. Chin. Integr. Med., 9, 824 (2011).

4. W.Q. Li, C.H. Jiang, S.S. Chu and M.X. Zuo, Molecules, 15, 5831 (2010).

5. Committee Chinese Pharmacopoeia Chinese Pharmacopoeia, 7, 62 (2005).

6. Y.H. Yao, J. Qin, B.L. Zhang and M.L. Ren, Sci. Technol. Food Ind., 31, 71 (2010).

7. V.A. Isidorov, U. Krafewska, V.T. Vinogorova, L.V. Vetchinnikova, I.L. Fuksman and K. Bal, Biochem. System. Ecol., 32, 1 (2004).

8. S. Sreelatha and P.R. Padma, Plant Foods Human Nutr., 64, 303 (2009).

9. L. Donatelli and F. Buffon, Pharmacol., 1, 4 (1948). 